\title{
NEWS AND NOTES
}

\section{NOTICE TO CONTRIBUTORS}

Space limitations and the ever-increasing volume of requests received by the REviEw prohibit the publication of notes relating to lecture series, symposia, seminars or new graduate programs sponsored by individual institutions.

Items relating to staff appointments and promotions will be accepted from department chairmen only.

\section{WASHINGTON OFFICE ACTIVITIES}

Congressional Study Project-A major project involving research on Congress was initiated under Association auspices shortly after the first of the year. Providing for a comprehensive study of the problems of Congressional organization and operation, this project was made possible by a grant from the Carnegie Corporation of New York.

The Association will administer the project. It will be carried out under the direction of Professor Ralph K. Huitt, of the University of Wisconsin, and is scheduled for completion in two years.

In addition to the research program, the grant provides for a series of conferences among political scientists, for continuing consultation between the project's research staff and members of Congress, and for establishment of an Advisory Committee of outstanding political scientists interested in the general field of Congressional operations.

Results of the study are to be published in an appropriate manner in monograph and book form.

Review Reprinting-For the past several years the Association has been negotiating with a number of firms interested in securing reprint rights for out-of-print issues and volumes of the American Political Science Review. These negotiations are now complete, and the Association recently signed a contract with one of the world's largest reprinting firms, the Johnson Reprint Corporation, with headquarters in New York City and branch offices in Los Angeles, London, Frankfurt and Milan.

As approved by the Association's Executive Committee, the contract provides for high quality reprinting of all out-of-print issues. This means that Volumes $I$ to $V$, for instance, which have been out-of-print for many years, will once again be available to libraries, institutions and individuals by July, 1964 .
Additionally, the Johnson firm has agreed to take over sales of back issues of the Review; these will continue to be available to purchasers at a price established by the Association. Further details of both the reprinting and back issues arrangements will be announced by the Association and by the Johnson Reprint Corporation. Meanwhile, back issues may be ordered directly from the Johnson firm at 111 Fifth Avenue, New York 3, New York.

Annual Meeting Site-The Association has completed arrangements for the 1965 Annual Meeting, which will be held in Washington, D. C., September 8 to 11 . Headquarters for the meeting will be the Sheraton-Park Hotel, and rates of $\$ 8.00$ for single rooms and $\$ 12.00$ for twins will apply for all Association members attending. (These rates are $\$ 1.00$ less in each category than were in effect during the 1962 Annual Meeting in Washington.) Pre-registration cards will be mailed to all members well in advance of the meeting date.

Senate Youth Program-The Association, within the framework of its Social Studies Project, conducted the second Annual Senate Youth Program during the week of January 27. Participating in the Program, financed by the William Randolph Hearst Foundation, were 102 high school student leaders-two from each state and the District of Columbia.

On the program during the week were meetings with the leadership of both Houses of Congress and top level Executive Branch officials. In addition, the students spent time as interns in Senatorial offices and attended a series of seminars and lectures conducted by political scientists and other experts in the field of government and politics.

Legislative Seminar-During the week of February 10, the Association co-sponsored the second 
in a series of legislative operations seminars for career Federal executives, Civil Service Grades 15 to 18 . This seminar program was inaugurated last year, at the request of the U. S. Civil Service Commission, in an effort to enhance the career civil servants' knowledge and understanding of executive-legislative relations through an examination in depth of Congressional functions and processes. A third seminar, also to be conducted by political scientists, members of the House and Senate, and Executive Branch officials, is scheduled during the month of May.

\section{PROFESSIONAL CONFERENCES}

The Conference on Soviet and Communist Studies of the American Political Science Association met in New York in September for its annual business meeting. Marshall D. Shulman, Fletcher School, retiring chairman, presided. George Fischer of the department of government at Cornell University was elected vice-chairman for 1963-64 and chairman for 1964-65. Robert C. Tucker of Princeton University, the present chairman, appointed a nominating committee composed of Louis Nemzer, Ohio State University, chairman; Alex Dragnich, Vanderbilt University; and George Fischer. The guest of honor, Louis Fischer, spoke on his forthcoming biography of Lenin.

The Society for International Development held its sixth world conference in Washington, D. C., March 16-18, 1964. The theme of the conference was "Human Factors in International Development: Motivations and Methods"

\section{OTHER ACTIVITIES}

\section{ACCESS TO THE RECORDS OF THE DEPARTMENT OF STATE}

The Department of State has recently revised its rules governing access by researchers to its records. For many years the records of the Department have been divided for this purpose into three periods: open, restricted, and closed. The open period formerly ran through 1929; the restricted period covered 1930 through 1941; the closed period was from 1942 to the present. The new regulations retain the same three periods for access purposes, but the fixed dates have been removed in favor of a system of progressive opening geared to the publication of the Department's series Foreign Relations of the United States. Thus the closed period is now defined as the period in advance of the Foreign Relations series, and the beginning date of the closed period will be advanced automatically as the volumes in that series are published. The restricted period is defined as the ten years in back of the closed period, and the open period covers the records prior thereto.

Since the Foreign Relations volumes have now been published for 1942 and are being released for 1943 , this means that the terminal date of the restricted period has been advanced to 1943 while the terminal date of the open period has been advanced from 1929 to January 1, 1933.

Applications for access to records of the open period may be made direct to the National Archives, Washington, D. C. 20408. Applications for access to the restricted period should be made to the Historical Office, Department of State, Washington, D. C. 20520. Access to documents of the restricted period will be granted liberally to serious scholars, subject to review of their notes. It is not the Department's policy to grant access in the restricted period to undergraduates.

William M. Franklin Director, Historical Office Bureau of Public Affairs

December 1963. 